\title{
Apakah discovery learning dapat menumbuhkan keterampilan berpikir kritis? Respon siswa terhadap penggunaan UKBM pada Program Ilmu Sosial
}

\author{
Sri Sukartiningsih \\ MAN 2 Probolinggo \\ Probolinggo, Indonesia \\ Memenk27@gmail.com \\ Sarmini \\ Fakultas Ilmu Sosial dan Hukum Universitas Negeri Surabaya \\ Surabaya, Indonesia \\ sarmini@unesa.ac.id

\section{Jacky} \\ Fakultas Ilmu Sosial dan Hukum Universitas Negeri Surabaya \\ Surabaya, Indonesia \\ sarmini@unesa.ac.id \\ Agung Dwi Bahtiar El Rizaq* \\ Fakultas Tarbiyah IAIN Madura \\ Pamekasan, Indonesia \\ elrizaq@iainmadura.ac.id
}

\begin{abstract}
Critical thinking is one of the main skills that students must mastered in order to respond the challenges of globalization and the demands of skilled labor in this disruption era. Various learning models, methods and strategies are developed to meet these objectives. One of the way is the implementation of teaching materials in the form of Independent Learning Activity Unit (UKBM) in learning to foster students' critical thinking skills. The focus of this study is to describe students' responses to the implementation of UKBM in social science programs based on discovery learning to foster students' critical thinking skills. This study used an explanatory mix method research design with a percentage technique. Data were collected through questionnaires, observations and interviews. Data analysis was carried out in four stages; collection, reduction, presentation and drawing conclusions. This study found several things: 1) UKBM in social science programs are effectively foster critical thinking skills; 2) the most prominent assessment is the aspect of student interest in an attractive UKBM design; 3) the assessment is less prominent in the aspect of discovery learning approach in learning because it requires a long time and seriousness of teachers and students. This paper recommends the implementation of other learning models at UKBM to foster critical thinking skills.
\end{abstract}

Keywords; Discovery learning; Independent Learning Activity Unit; Critical Thinking Skills 


\begin{abstract}
Berpikir kritis menjadi salah satu keterampilan utama yang harus dimiliki siswa sebagai bekal menjawab tantangan globalisasi dan tuntutan tenaga kerja terampil pada era disrupsi. Berbagai model, metode dan strategi pembelajaran dikembangkan untuk memenuhi tujuan tersebut. Salah satunya melalui implementasi bahan ajar berupa Unit Kegiatan Belajar Mandiri (UKBM) dalam pembelajaran untuk menumbuhkan keterampilan berpikir kritis siswa. Fokus kajian ini adalah mendeskripsikan respon siswa terhadap penggunaan UKBM di program ilmu sosial berbasis discovery learning untuk menumbuhkan keterampilan berpikir kritis siswa. Kajian ini menggunakan desain penelitian mix method tipe explanatory dengan teknik persentase. Data dikumpulkan melalui angket, observasi dan wawancara. Analisis data dilakukan dengan empat tahap; pengumpulan, reduksi, penyajian dan penarikan kesimpulan. Penelitian ini menemukan beberapa hal: 1) UKBM Program ilmu sosial efektif digunakan guna menumbuhkan keterampilan berpikir kritis; 2) penilaian paling menonjol adalah aspek ketertarikan siswa pada desain UKBM yang menarik; 3) penilaian kurang menonjol pada aspek pendekatan discovery learning dalam pembelajaran karena membutuhkan waktu panjang serta keseriusan guru dan siswa. Tulisan ini merekomendasikan implementasi model pembelajaran lain pada UKBM untuk menumbuhkan keterampilan berpikir kritis.
\end{abstract}

Kata Kunci: discovery learning; Unit Kegiatan Belajar Mandiri (UKBM); keterampilan berpikir kritis

Diterima 26 April 2021, Dipublikasikan April 2021

\title{
PENDAHULUAN
}

Socrates mendefinisikan pemikiran kritis sebagai seni penghakiman, artinya bagaimana mengevaluasi sesuatu dalam hal aspek baik dan buruknya (Sahika, 2017). Sedangkan Robert Ennis mendefinisikan pemikiran kritis sebagai pemikiran reflektif rasional dan fokus pada pengambilan keputusan pada sesuatu yang harus dipercaya atau dilakukan (Astra, 2018). Secara umum pengertian pemikiran kritis dalam penelitian ini merupakan sebuah penilaian atas beberapa pertanyaan-pertanyaan dengan memperhatikan cara logis dan bukti relevan.

Salah satu efek paling menonjol dari globalisasi dan kapitalisme adalah peningkatan permintaan pada tenaga yang terampil (Marquez, 2017), oleh karena itu, tujuan program pendidikan diarahkan pada bagaimana membekali siswa dengan kemampuan berpikir kritis (Tiruneh et al., 2018). Keterampilan berpikir kritis akan bermanfaat bagi siswa dalam menghadapi arus informasi yang kuat pada abad 21. Berpikir kritis dibutuhkan dalam proses memperoleh informasi, menanyakan keakuratan dan keandalan informasi serta membaca data dan indikator dengan bukti yang benar. Hal ini akan sangat penting bagi pengambilan keputusan yang bermanfaat bagi orang (Hategan, 2018).

Pendidikan memiliki peran penting dalam menumbuhkan kemampuan berpikir kritis siswa. Mereka harus dilatih menjadi pemikir kritis agar menjadi generasi yang terbuka, sensitif, memahami keyakinan dan kepercayaan, serta memahami nilai-nilai orang lain sehingga tidak mudah diperalat oleh sebuah sistem (Marquez, 2017). Guru memegang peran utama pula dalam menghasilkan siswa yang memiliki pemikiran bebas, kritis dalam masyarakat yang demokratis (Sahika, 2017).

Sebuah penelitian dilakukan oleh (Walter, Christel; Walter, 2017) tentang sistem sekolah di Jerman. Dalam penelitiannya mereka mempertanyakan apakah berpikir kritis menjadi variabel mediator untuk meningkatkan performa siswa di sekolah. Hasil penelitian menunjukkan bahwa 


\section{Apakah discovery learning dapat menumbuhkan keterampilan berpikir kritis? Respon siswa terhadap penggunaan UKBM pada Program Ilmu Sosial}

tujuan sistem sekolah menjadi faktor penentu berjalannya proses pembelajaran. Pembelajaran yang diatur sendiri dan mengembangkan otonomi siswa dalam berpikir kritis ternyata lebih mendorong keaktifan siswa dalam bidang akademik.

Serupa dengan Jerman, di Filipina, pendidikan diarahkan dan didorong untuk mengembangkan pedagogi kritis, bukan lagi taksonomi. Taksonomi memiliki sifat reduktif sehingga kurang dalam meningkatkan keterampilan berpikir kritis siswa, sedangkan pedagogi kritis akan membawa siswa ke meja dialog dengan mengajarkan mereka cara meningkatkan dan menerima pertanyaan tanpa sikap permusuhan dan karakter pemikiran yang kritis (Marquez, 2017).

Ironinya, banyak mata pelajaran dan pengajaran pemikiran kritis di Filipina tersebut tetap menghasilkan siswa yang tidak kritis. Kendala utama sebagai penyebabnya adalah sistem pengajaran yang didaktis. Pemikiran kritis dapat diajarkan kepada siswa ketika mereka diberi kebebasan untuk bertanya, mengeksplorasi kemungkinan dan terlibat dalam diskusi yang bermakna. Hal ini dapat dilakukan melalui pengajaran reflektif (Marquez, 2017).

Dari penelitian (Tan, 2017) di Singapura, disebutkan bahwa mengajarkan pemikiran kritis kepada siswa memiliki dua tantangan. Pertama, pemikiran kritis harus menjadi kebutuhan bagi pembuat kebijakan sebagai payung pengajaran untuk mengatasi segala bentuk kendala. Kedua diperlukan kemanjuran guru untuk melibatkan siswa dalam pembelajaran dan mengatasi tantangan sosial budaya yang dihadapi. Oleh karena itu sangat diperlukan penambahanpenambahan literatur bagi guru dan siswa.

Pemikiran kritis adalah suatu bentuk pemikiran tingkat tinggi yang melibatkan semua proses berpikir seperti bagaimana memperoleh informasi, memahami informasi, menganalisis, mengkorelasikan, menafsirkan, mengevaluasi, membuat penilaian, dan membuat penilaian tentang baik-buruk atau benar-salah (Sahika, 2017). Fenomena tersebut sinergis dengan model pembelajaran discovery learning, dalam sintaknya siswa diajak berpikir dari mudah menjadi sulit. Sintak discovery learning dimulai dari tahap stimulation, problem statement, data collecting, data processing, verification dan generalization.

Model pembelajaran Discovery learning dalam penelitian ini akan diintegrasikan dalam sebuah pedoman belajar siswa yang dikenal dengan Unit Kegiatan Belajar Mandiri (UKBM). Dalam model discovery learning, siswa akan diberikan berbagai aktivitas untuk membangun pengetahuan mereka sendiri secara optimal, seperti observasi, pengalaman dan penalaran (Ellizar et al., 2018).

UKBM merupakan salah satu instrumen dalam pembelajaran disusun menjadi unit-unit kegiatan belajar sebagai pegangan dalam melaksanakan pembelajaran. Belajar menggunakan UKBM menuntut siswa untuk melakukan pengelolaan beban belajar mandiri. Selaras dengan kemampuan dan kompetensi masing-masing. UKBM digunakan pada kelas yang melaksanakan program Sistem Kredit Semester (SKS).

Discovery learning sebagai metode pembelajaran digunakan sebagai basis dalam mengintegrasikan sintaksisnya dalam UKBM untuk meningkatkan keterampilan berpikir kritis. Model pembelajaran discovery learning mengarahkan peserta didik tidak diberikan jawaban, melainkan disuguhi uraian materi yang mengarahkan untuk menemukan jawaban secara mandiri. Hal ini dibangun dalam rangka membangun keterampilan pemecahan masalah di mana peserta didik belajar dari pengalaman sendiri selama belajar dan dikorelasikan dengan pengetahuan sebelumnya. Secara nyata, pembelajaran ini mengarahkan peserta didik untuk 
membangun interaksi dengan lingkungannya, menjelajahi dan mengorganisir obyek, serta proses dialektika dengan pertanyaan dan kontroversi atau melakukan eksperimen.

Pentingnya kemampuan berpikir kritis yang dikuasai siswa merupakan salah satu kompetensi utama yang harus dimiliki di masa disrupsi dewasa ini. Berbagai kajian yang telah diuraikan telah menunjukkan bahwa discovery learning terbukti dapat digunakan sebagai basis model pembelajaran dalam menumbuhkan keterampilan berpikir kritis siswa. Selaras dengan inti sari discovery learning yang mengarahkan siswa dalam membangun keterampilan berpikir kritis, UKBM menitik beratkan pada penyediaan materi dan kegiatan belajar tanpa membatasi kemampuan siswa. Untuk mengetahui respon siswa terhadap UKBM Program ilmu sosial berbasis discovery learning dikaji menggunakan sudut pendekatan teori belajar sosial Albert Bandura yang menitik beratkan pada membangun kompetensi peserta didik dalam mengolah informasi dari pemaknaan suatu model atau ilustrasi dalam ranah kognitif sebagai basis untuk melakukan suatu tindakan (Lesilolo, 2019).

\section{METODE}

Penelitian ini menggunakan desain mix method research tipe explanatory dengan teknik persentase sesuai pendapat Sugiyono (2005) desain penelitian yang dilakukan untuk menganalisis suatu fenomena hasil penelitian namun tidak dapat menjadi basis untuk membuat kesimpulan secara universal (Masrizal, 2011). Data dikumpulkan melalui angket, observasi dan wawancara. Analisis data dilakukan dengan empat tahap; pengumpulan, reduksi, penyajian dan penarikan kesimpulan. Kajian ini bertujuan untuk mengetahui respon siswa terhadap Unit Kegiatan Belajar Mandiri (UKBM) Program Ilmu Sosial berbasis discovery learning untuk menumbuhkan keterampilan berpikir kritis. Subjek dalam penelitian ini adalah kelas X IPS di MAN 2 Probolinggo. Teknik pengumpulan data melalui angket, observasi dan wawancara.

\section{HASIL DAN PEMBAHASAN}

\section{Respon siswa terhadap UKBM Program Ilmu Sosial berbasis discovery learning untuk menumbuhkan keterampilan berpikir kritis}

Tujuan penelitian ini adalah untuk menunjukkan bagaimana respon siswa terhadap paket belajar yang disebut Unit Kegiatan Belajar Mandiri (UKBM) Program ilmu sosial. Beberapa aspek yang akan dinilai yaitu aspek ketertarikan, materi, bahasa dan pendekatan discovery learning.

\section{Aspek ketertarikan}

Pada aspek ketertarikan, siswa akan merespon dan memberi masukan bagaimana UKBM ini dapat membantu mereka belajar program ilmu sosial dan apa yang membuat mereka tertarik (Tabel 3.1). Berdasarkan angket respon yang disebarkan, siswa yang belajar menggunakan UKBM Program ilmu sosial yang dikembangkan menilai sangat baik $(90 \%)$ dan tertarik untuk belajar dengan UKBM ini seperti di uraikan pada "Respon Siswa Terhadap UKBM Aspek Ketertarikan (Tabel 3.1)". Dari respon tersebut menunjukkan bahwa UKBM Program ilmu sosial ini memiliki tampilan yang menarik sehingga menumbuhkan semangat dalam belajar Program ilmu sosial. Selain itu, belajar dengan UKBM Program ilmu sosial ini menjadi tidak membosankan dan sangat mendukung untuk menguasai pelajaran. Belajar Program ilmu sosial yang semula dinilai hanya sekedar pelajaran menghafal, melalui UKBM ini siswa diajak untuk 


\section{Apakah discovery learning dapat menumbuhkan keterampilan berpikir kritis? Respon siswa terhadap penggunaan UKBM pada Program Ilmu Sosial}

belajar dengan cara yang bervariasi yaitu literasi, observasi, diskusi, presentasi bahkan melakukan penelitian sederhana.

Tabel 3.1 Hasil Rekapitulasi Respon Siswa Terhadap UKBM Aspek Ketertarikan

\begin{tabular}{llc}
\hline No. & \multicolumn{1}{c}{ Aspek } & Skor \\
\hline 1. & Tampilan UKBM Program ilmu sosial menarik & 5 \\
2. & UKBM Program ilmu sosial membuat siswa lebih bersemangat dalam belajar & 5 \\
3. & $\begin{array}{l}\text { Dengan menggunakan UKBM Program ilmu sosial, belajar menjadi tidak } \\
\text { membosankan }\end{array}$ & 4 \\
4. & $\begin{array}{l}\text { UKBM Program ilmu sosial mendukung siswa untuk menguasai pelajaran } \\
\text { Program ilmu sosial }\end{array}$ & 5 \\
5. & $\begin{array}{l}\text { Adanya kata motivasi dalam UKBM Program ilmu sosial mempengaruhi sikap dan } \\
\text { gaya belajar siswa }\end{array}$ & 4 \\
6. & Ilustrasi memberikan motivasi untuk mendalami materi & 5 \\
\hline & Jumlah & 27 \\
\hline & Persentase & $90 \%$ \\
\hline
\end{tabular}

Sumber : data angket diolah

Tampilan dan motivasi yang terdapat pada UKBM merupakan salah satu rangsangan yang dapat menumbuhkan kompetensi dan kemampuan siswa. Hal tersebut senada dengan hasil kajian yang menunjukkan bahwa perkembangan kognitif individu berasa dari interaksi sosial maupun kultural di sekitar lingkungannya (El Rizaq \& Sarmini, 2020). Salah satu cara yang dilakukan UKBM dalam menumbuhkan aspek kognitif siswa melalui motivasi yang disajikan melalui gambar dan ilustrasi sesuai dengan respon mengenai "Ilustrasi memberikan motivasi untuk mendalami materi (Tabel 3.1)" mendapatkan skor sempurna. Hal tersebut juga mampu mendorong siswa belajar menemukan konsep-konsep Program ilmu sosial secara mandiri, membentuk karakter sosial dan emosional yang baik seperti tanggung jawab dan mandiri. Akan tetapi belum semua siswa tergugah motivasinya untuk lebih semangat belajar program ilmu sosial. Siswa yang terbiasa dengan bimbingan guru sedikit kesulitan untuk beradaptasi.

\section{Aspek materi}

Pada aspek materi, siswa akan menilai dan memberikan masukan mengenai penyajian materi dalam UKBM serta bagaimana bagian-bagian yang ditampilkan dalam UKBM ini mampu mendorong siswa belajar secara mandiri (Tabel 3.2).

Tabel 3.2 Hasil Rekapitulasi Respon Siswa Terhadap UKBM Aspek Materi

\begin{tabular}{|c|c|c|}
\hline No. & Aspek & Skor \\
\hline 1. & $\begin{array}{l}\text { Penyampaian materi dalam UKBM Program ilmu sosial terkait dengan kehidupan } \\
\text { sehari-hari }\end{array}$ & 5 \\
\hline 2. & Penyajian materi mudah dipahami & 4 \\
\hline 3. & Terdapat bagian untuk mengarahkan penemuan konsep secara mandiri & 4 \\
\hline 4. & Mengakomodir kesempatan diskusi dengan teman & 4 \\
\hline 5 . & UKBM Program ilmu sosial memberikan kesempatan melakukan Refleksi & 5 \\
\hline 6. & UKBM memuat tes evaluasi ketercapaian materi & 5 \\
\hline & Jumlah & 26 \\
\hline & Persentase & $87 \%$ \\
\hline & Kategori & Sangat Baik \\
\hline
\end{tabular}

Sumber : data angket diolah 
Pada segi materi, UKBM Program ilmu sosial yang dikembangkan dinilai siswa sangat baik (87\%). Uraian mengenai "materi, latihan soal dan contoh-contoh yang disajikan terkait dengan kehidupan sehari-hari (Tabel 3.2)" mendapatkan penilaian sempurna. Pada bagian-bagian ilustrasi dan gambar mampu mendorong siswa untuk menemukan konsep Program ilmu sosial secara mandiri maupun berkolaborasi dengan teman melalui diskusi dengan bimbingan guru. Melalui kegiatan refleksi, siswa dapat mengukur pemahamannya dari materi yang telah dipelajari. UKBM juga mengarahkan siswa untuk menguji pemahaman tersebut melalui tes evaluasi yang disajikan di bagian akhir UKBM Program ilmu sosial.

Materi yang disajikan dalam UKBM Program ilmu sosial berbasis discovery learning ini dibuat secara runtut dan sistematis dan disajikan dengan bahasa yang mudah dipahami siswa. Namun berdasar penilaian siswa ada beberapa siswa yang menilai sulit memahami istilahistilah dalam program ilmu sosial yang ditampilkan dalam UKBM.

\section{Aspek bahasa}

Pada aspek bahasa, siswa akan memberikan respon, kritikan dan masukan tentang penggunaan bahasa dalam UKBM dapat membantu memahami belajar program ilmu sosial (Tabel 3.3) .

Tabel 3.3 Hasil Rekapitulasi Respon Siswa Terhadap UKBM Aspek Bahasa

\begin{tabular}{|c|c|c|}
\hline No. & Aspek & Skor \\
\hline 1. & Kalimat yang digunakan jelas & 5 \\
\hline 2. & Bahasa yang digunakan mudah dimengerti & 4 \\
\hline \multirow[t]{4}{*}{3.} & Penggunaan huruf sesuai & 4 \\
\hline & Jumlah & 13 \\
\hline & Persentase & $87 \%$ \\
\hline & Kategori & Sangat Baik \\
\hline
\end{tabular}

Sumber : data angket diolah

Berdasarkan angket yang diberikan kepada siswa, penilaian UKBM Program ilmu sosial pada aspek bahasa memperoleh respon sangat baik (87\%). Menurut siswa, "UKBM Program ilmu sosial ini menggunakan kalimat yang jelas (Tabel 3.3)" mendapatkan penilaian sempurna. Pada aspek yang lain, pemilihan huruf juga mempermudah siswa untuk membaca, penggunaan kalimat efektif telah jelas dan mudah dipahami. Hal ini menunjukkan bahwa UKBM Program ilmu sosial ini dapat direkomendasikan untuk digunakan sebagai pendamping siswa dalam belajar Program ilmu sosial.

\section{Aspek pendekatan discovery learning}

Pada aspek ini, siswa memberikan tanggapan mengenai pendekatan discovery learning yang diintegrasikan dalam UKBM Program ilmu sosial (Tabel 3.4). Hasil penilaian siswa terhadap UKBM Program ilmu sosial pada aspek penilaian pendekatan discovery learning sesuai uraian Tabel 3.4 menunjukkan kategori sangat baik (86\%). Pada penilaian karakteristik discovery learning telah tampak dalam UKBM Program ilmu sosial yang dikembangkan. Pertama, UKBM mampu memberikan penekanan pada pembangunan argumentasi siswa dengan mengaitkan pada pengalaman siswa. Kegiatan belajar yang ada berisi latihan-latihan untuk melatih kemampuan berargumentasi. Kedua, UKBM mampu meningkatkan kemandirian belajar karena siswa dituntut untuk mengerjakan secara mandiri, dengan atau tidak didampingi oleh guru. Ketiga, UKBM mampu menumbuhkan keterampilan berpikir kritis, terlihat dari 


\section{Apakah discovery learning dapat menumbuhkan keterampilan berpikir kritis? Respon siswa terhadap penggunaan UKBM pada Program Ilmu Sosial}

tersedianya latihan soal yang mampu menggugah siswa untuk belajar eksplorasi, bertanya, mencari tahu serta menyelesaikan masalah. Keempat, UKBM mampu mendorong siswa berkolaborasi dengan guru dan teman sebaya melalui kegiatan diskusi dan kerja kelompok pada kegiatan belajar.

Tabel 3.4 Hasil Rekapitulasi Pada Aspek Pendekatan Discovery learning

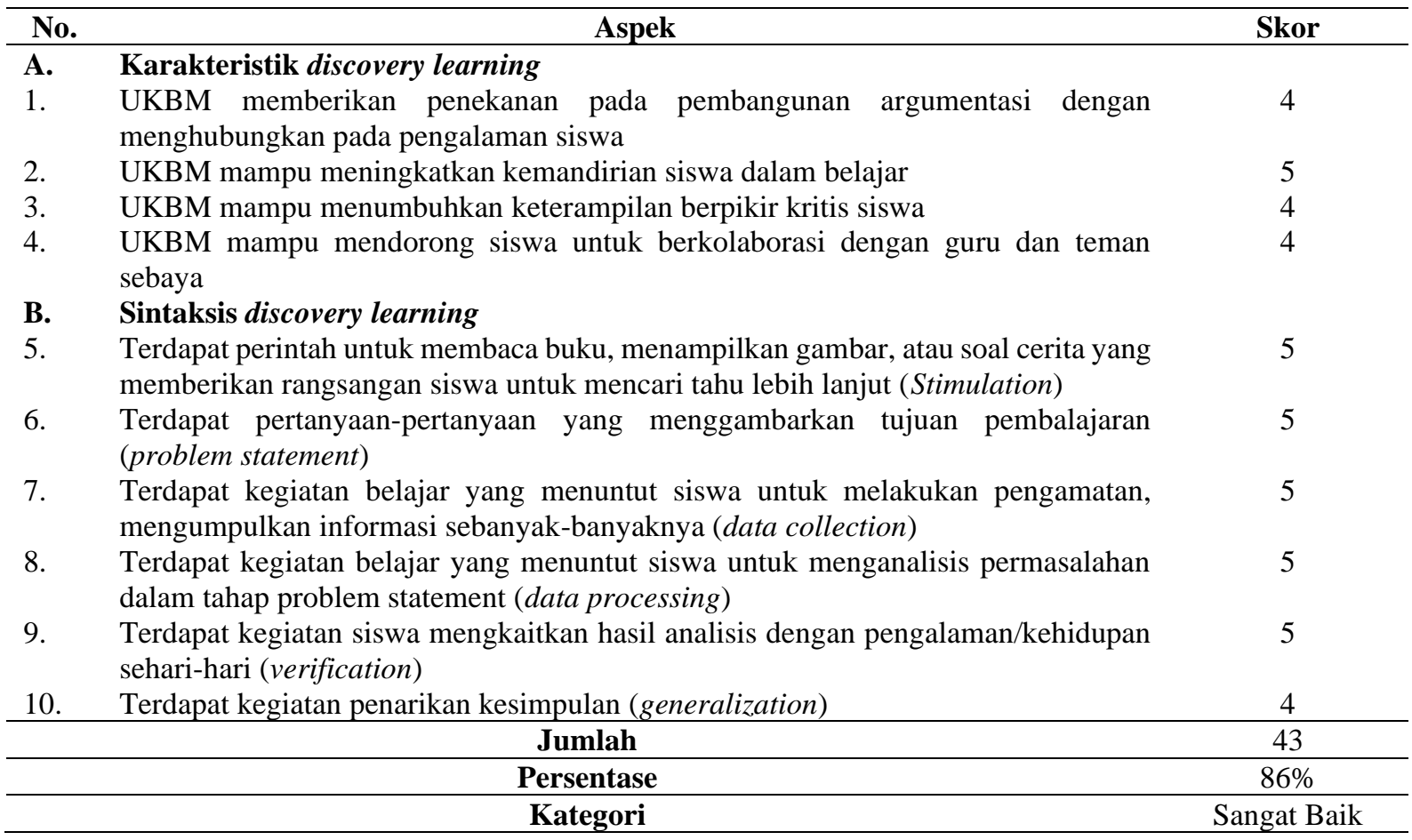

Sumber : data angket diolah

Penilaian sintaksis discovery learning lebih melihat bagaimana tahapan-tahapan belajar discovery learning terimplementasi dalam UKBM. Menurut siswa, UKBM Program ilmu sosial yang digunakan dalam belajar telah menyajikan sintaksis discovery learning pada proses pembelajaran Program ilmu sosial, dimulai dari tahap stimulation, problem statement, data collection, data processing, verification dan generalization. Pada tahap awal (stimulus), UKBM menyajikan adanya perintah membaca buku, menampilkan gambar maupun ilustrasi pancingan yang merangsang siswa untuk mengetahui lebih jauh. Dilanjutkan pertanyaanpertanyaan yang terkait dengan tujuan pembelajaran merupakan tahap problem statement. Tahap pengumpulan dan proses data dilakukan siswa dengan membaca literatur, mengamati obyek, wawancara serta diskusi kelompok. Kegiatan analisis data, penyelesaian masalah, presentasi dan menyimpulkan merupakan kegiatan penutup dalam tahapan-tahapan belajar discovery learning.

Penilaian/respon siswa terhadap UKBM terhadap UKBM Program ilmu sosial berbasis discovery learning ini akan menjadi sumber penilaian akhir bahwa UKBM Program ilmu sosial layak untuk digunakan dalam pembelajaran Program ilmu sosial (Tabel 3.5). Dari rekapitulasi yang diuraikan Tabel 3.5 menunjukkan bahwa secara keseluruhan penilaian terhadap UKBM Program ilmu sosial berbasis discovery learning untuk kelas X IPS ini mendapatkan penilaian dengan predikat sangat baik (88\%). Respon tersebut menunjukkan bahwa UKBM Program ilmu sosial efektif digunakan dalam kelas IPS. UKBM Program ilmu sosial yang dikembangkan 
dinilai dapat membantu guru mencapai tujuan pembelajaran yaitu menumbuhkan keterampilan berpikir kritis dan meningkatkan kemandirian belajar siswa.

Tabel 3.5 Rekapitulasi Respon Siswa Terhadap UKBM Program ilmu sosial Berbasis Discovery learning

\begin{tabular}{|c|c|c|}
\hline No. & Aspek & Prosentase \\
\hline 1. & Ketertarikan siswa & 90 \\
\hline 2. & Materi & 87 \\
\hline 3. & Kebahasaan & 87 \\
\hline 4. & Pendekatan discovery learning & 86 \\
\hline & Rata-rata Persentase & $88 \%$ \\
\hline & Kategori & Sangat Baik \\
\hline
\end{tabular}

Sumber : data angket diolah

Penggunaan bahan ajar dapat membangun kemampuan berpikir kritis telah terbukti dapat dilakukan sesuai respon siswa terhadap bahan ajar terintegrasi jenjang sekolah dasar (Amini, 2017). Senada dengan hasil penelitian tersebut, secara umum UKBM yang diuji coba telah sesuai dengan kebutuhan siswa dan dapat meningkatkan keterampilan berpikir kritis berdasarkan penilaian ahli, tanggapan guru dan siswa.

\section{Perspektif teori belajar sosial Albert Bandura: Belajar sebagai proses kognitif}

Proses belajar penemuan yang terdiri dari enam tahap diintegrasikan ke dalam bagian-bagian di UKBM secara sistematis dan runtut. Berikut sintak discovery learning yang diintegrasikan dalam UKBM. Pada tahap stimulasi, siswa menghadapi suatu masalah yang menimbulkan keinginan untuk menyelidiki, siswa diberi ilustrasi/pertanyaan, saran untuk memperkaya literasi, atau kegiatan lain yang mengarah pada pemecahan masalah. Pada UKBM, tahap ini ditempatkan pada tahapan proses belajar. Siswa diberi ilustrasi gambar atau cerita dengan tujuan agar ada ketertarikan maupun rasa ingin tahu untuk mempelajari materi yang akan dipelajari.

Pada tahap pernyataan atau identifikasi masalah (problem statement) sebagai kelanjutan tahap stimulasi. Tahapan ini mengarahkan siswa untuk mengidentifikasi sebanyak mungkin masalah atau problem yang relevan dengan kajian pelajaran, kemudian dipilih untuk dirumuskan sebagai hipotesis. Pada UKBM tahap ini ditampilkan di kegiatan inti yaitu pada petunjuk umum UKBM dan kegiatan belajar. Siswa diminta untuk membaca referensi serta mengerjakan latihan soal sebagai bentuk identifikasi masalah.

Tahap ini menitikberatkan pada siswa untuk mengumpulkan informasi sebanyakbanyaknya. Kegiatan dilakukan dengan kajian literatur, mengamati, wawancara maupun melakukan penelitian. Data yang telah diperoleh pada tahap sebelumnya, kemudian diidentifikasi, diklasifikasikan, dianalisis sesuai dengan jenis permasalahan dan tingkat pemahaman siswa. Dalam memproses data, siswa diberi kesempatan untuk mandiri, diskusi dengan teman atau meminta arahan guru.

Tahap Verifikasi, siswa sudah sampai pada tahapan belajar menemukan terori, konsep, aturan atau pemahaman melalui contoh yang biasa terjadi dalam kehidupan sehari-hari. Siswa belajar menghubungkan konsep yang dipelajari dengan realitas yang bisa dijumpai. Dan tahap generalisasi, Siswa diajak belajar menemukan solusi pada permasalahan yang disajikan (studi kasus), serta belajar menarik kesimpulan secara mandiri (generalisasi). 


\section{Apakah discovery learning dapat menumbuhkan keterampilan berpikir kritis? Respon siswa terhadap penggunaan UKBM pada Program Ilmu Sosial}

Model discovery learning memberikan kebebasan kepada siswa untuk belajar menemukan konsep sendiri. Pembelajaran pada kelas SKS memiliki tujuan yang sama pada penggunaan UKBM. Belajar menggunakan UKBM bertujuan untuk mengasah kemandirian siswa, siswa diberi kebebasan untuk menyelesaikan UKBM sesuai dengan kompetensi dan kemampuannya. Masing-masing siswa akan berbeda kemajuan belajarnya, dan UKBM menjadi ukurannya. Model pembelajaran yang demikian akan memudahkan guru untuk mengidentifikasi kapasitas siswa sebagai pembelajar cepat, normal dan lambat.

Untuk menyelesaikan UKBM dibutuhkan motivasi belajar dan tanggung jawab pada diri siswa, apabila tidak memiliki keduanya maka siswa akan tertinggal dari temannya. Belajar dengan menggunakan UKBM membebaskan siswa mengatur dirinya sendiri. Apabila meminjam istilah dalam teori belajar Bandura, proses belajar dengan UKBM membutuhkan pengaturan diri (self-regulation). Bandura mendefinisikan pengaturan diri sebagai tindakan mengelola pikiran dan perasaan untuk memungkinkan tindakan diarahkan untuk keberhasilan di sekolah (Hategan, 2018)

Menurut Bandura, self-regulation siswa terbentuk karena beberapa faktor yaitu motivasi internal, kompleksitas pembelajaran, tujuan pembelajaran, pemenuhan diri dan proses persaingan (Ellizar et al., 2018; Nurul Istikomah, Stefanus Christian Relmasira, 2017). Motivasi internal terbentuk ketika siswa mulai menumbuhkan semangat dalam dirinya untuk belajar. Kompleksitas pembelajaran merupakan level penguasaan keterampilan yang lebih sederhana yang harus lebih dahulu dikuasai sebelumnya, sehingga memudahkan untuk menguasai keterampilan yang lebih tinggi. Tujuan pembelajaran berupa target capaian sebagai acuan dalam melaksanakan pembelajaran. Pemenuhan diri merupakan rangkaian evaluasi yang dilakukan siswa apakah proses belajar yang telah dilakukan sesuai dengan tahapan untuk mencapai tujuan pembelajaran yang telah ditetapkan. Sedangkan proses persaingan dapat menumbuhkan semangat untuk menjadi lebih baik.

\section{SIMPULAN}

Unit Kegiatan Belajar Mandiri (UKBM) sebagai bagian dari bahan ajar yang digunakan guru dalam pembelajaran Program ilmu sosial. UKBM ini dibuat dengan mengintegrasikan sintak discovery learning dalam urutan kegiatan belajar, dengan tujuan untuk menumbuhkan keterampilan berpikir kritis siswa.

Dari hasil penelitian ditemukan kesimpulan, pertama, berdasarkan respon siswa dapat dijelaskan bahwa UKBM Program ilmu sosial berbasis discovery learning mampu menumbuhkan keterampilan berpikir kritis siswa. Kedua, aspek yang paling menonjol dalam penilaian siswa adalah ketertarikan mereka terhadap UKBM. Hal ini menunjukkan bahwa penampilan dengan banyaknya gambar yang terdapat dalam UKBM dapat memicu semangat dan motivasi belajar siswa. Ketiga, UKBM dengan pendekatan discovery learning membiasakan siswa untuk mencari pengetahuannya secara mandiri yang menuntut motivasi belajar dan tanggung jawab atau bagi Bandura disebut sebagai self-regulation namun proses pembiasaan tersebut membutuhkan jenjang waktu yang cukup panjang.

\section{DAFTAR PUSTAKA}

Amini, R. (2017). The Development of Integrated Learning Based Students' Book to Improve Elementary School Students' Competence. Unnes Science Edication Journal, 6(2), 15861592.

Astra, I. M. (2018). Character building in physics learning for Indonesia children. Journal of 
Physics: Conference Series, 1040(1). https://doi.org/10.1088/1742-6596/1040/1/012043

El Rizaq, A. D. B., \& Sarmini. (2020). Integrasi nilai karakter lokal dalam pengembangan bahan ajar IPS untuk meningkatkan wawasan kebangsaan siswa. Jurnal Teori Dan Praksis Pembelajaran IPS, 5(1), 19-27. https://doi.org/10.17977/um022v5i12020p019

Ellizar, E., Hardeli, H., Beltris, S., \& Suharni, R. (2018). Development of Scientific Approach Based on Discovery Learning Module. IOP Conference Series: Materials Science and Engineering, 335(1). https://doi.org/10.1088/1757-899X/335/1/012101

Hategan, V. P. (2018). Critical Thinking, an Effective Educational Tool in Philosophical Counseling. Journal Plus Education, XIX(1), 262-272.

Lesilolo, H. J. (2019). Penerapan Teori Belajar Sosial Albert Bandura Dalam Proses Belajar Mengajar Di Sekolah. KENOSIS: Jurnal Kajian Teologi, 4(2), 186-202. https://doi.org/10.37196/kenosis.v4i2.67

Marquez, L. P. (2017). Critical thinking in philippine education: What we have and what we need. Journal for Critical Education Policy Studies, 15(2), 272-303.

Masrizal. (2011). Mixed Method Research. Jurnal Kesehatan Masyarakat, 6(1), 53-56.

Nurul Istikomah, Stefanus Christian Relmasira, A. T. A. H. (2017). Penerapan model discovery learning pada pembelajaran ips untuk meningkatkan keaktifan dan hasil belajar kognitif siswa sekolah dasar. Didaktika Dwija Indria, 6(3), 130-139.

Sahika. (2017). Curriculum Development Study for Teacher Education Supporting Critical Thinking. Eurasian Journal of Educational Research, 76(May), 37. https://doi.org/10.14689/ejer.2018.76.9

Tan, C. (2017). Teaching critical thinking: Cultural challenges and strategies in Singapore. British Educational Research Journal, 43(5), 988-1002. https://doi.org/10.1002/berj.3295

Tiruneh, D. T., De Cock, M., \& Elen, J. (2018). Designing Learning Environments for Critical Thinking: Examining Effective Instructional Approaches. International Journal of Science and Mathematics Education, 16(6), 1065-1089. https://doi.org/10.1007/s10763-017-9829$\mathrm{z}$

Walter, Christel; Walter, P. (2017). Is Critical Thinking a Mediator Variable of Student Performance in School? Educational Research Quarterly, 41(3), 3-24. 